\title{
Mass Spectrometric Study of the Photoionization of Some Fluorocarbons and Trifluoromethyl Halides*
}

\author{
Clemente Juan Noutary**
}

\begin{abstract}
(June 16, 1968)
The photoionization curves and the threshold energies for the molecule and several abundant fragment ions of $\mathrm{CF}_{4}, \mathrm{C}_{2} \mathrm{~F}_{6}, \mathrm{C}_{3} \mathrm{~F}_{8}, \mathrm{C}_{4} \mathrm{~F}_{10}, \mathrm{CF}_{3} \mathrm{H}, \mathrm{CF}_{3} \mathrm{Cl}, \mathrm{CF}_{3} \mathrm{Br}$, and $\mathrm{CF}_{3} \mathrm{I}$ have been measured. The threshold energies are correlated and the ionic heats of formation and some bond dissociation energies are calculated. It is apparent that the values obtained for the $\mathrm{CF}_{3}^{+}$ions are not the adiabatic ones, but include large amounts of excess energy. This excess is the lowest for the $\mathrm{CF}_{3}^{+}$from $\mathrm{CF}_{3} \mathrm{I}$ for which an explanation is suggested. Assuming that the excess is not zero for the last compound we obtain the following upper limits: $\left.\Delta H f_{0}^{\circ}\left(\mathrm{CF}_{3}\right)^{+} \leqslant+365.3 \mathrm{~kJ} \mathrm{~mol}^{-1}=+87.3 \mathrm{kcal} \mathrm{mol}^{-1} ; \mathrm{CF}_{3}\right)^{+} \leqslant 8.62 \mathrm{eV}$; $I\left(\mathrm{C}_{2} \mathrm{~F}_{5}\right)^{+} \leqslant 8.72 \mathrm{eV} ; I\left(\mathrm{C}_{3} \mathrm{~F}_{7}\right)^{+} \leqslant 8.70 \mathrm{eV} ; I\left(\mathrm{C}_{4} F_{9}\right)^{+} \leqslant 8.68 \mathrm{eV}$. From the mean value $\mathrm{D}\left(\mathrm{C}_{p}-\mathrm{C}_{p}\right)=402$ $\pm 2 \mathrm{~kJ} \mathrm{~mol}^{-1}=96.0 \pm 0.5 \mathrm{kcal} \mathrm{mol}^{-1}$ the bond dissociation energies $\mathrm{D}\left(C_{p}-C_{s}\right)=363 \pm 3 \mathrm{~kJ} \mathrm{~mol}^{-1}$ $=86.8 \pm 0.8 \mathrm{kcal} \mathrm{mol}^{-1}$ and $\mathrm{D}\left(\mathrm{C}_{s}-C_{s}\right)=337 \pm 4 \mathrm{~kJ} \mathrm{~mol}^{-1}=80.6 \pm 1.0 \mathrm{kcal} \mathrm{mol}^{-1}$ and $\mathrm{D}\left(C_{p}-\mathrm{F}\right)=525$ $\mathrm{kJ} \mathrm{mol}^{-1}=125.7 \mathrm{kcal} \mathrm{mol}^{-1}$ are calculated.
\end{abstract}

Key Words: $\mathrm{CF}_{4} ; \mathrm{C}_{2} \mathrm{~F}_{6} ; \mathrm{C}_{3} \mathrm{~F}_{8} ; \mathrm{C}_{4} \mathrm{~F}_{10} ; \mathrm{CF}_{3} \mathrm{H} ; \mathrm{CF}_{3} \mathrm{Cl} ; \mathrm{CF}_{3} \mathrm{Br} ; \mathrm{CF}_{3} \mathrm{I}$; heats of formation; ionization energies; mass spectrometric; photoionization; vacuum ultraviolet.

\section{Introduction}

The spectra, ionization and dissociation energies of various ions from fluorocarbons and trifluoromethyl halides have been measured by electron impact [1-11] ${ }^{1}$ or spectroscopically [12] by several authors. The heat of formation and the bond dissociation energies have also been measured or calculated by various methods [13-26]. Many of those values are not in good agreement. However, recent measurements have given improved values for some fundamental data-from which most bond energies are derived-such as the heat of formation of $\mathrm{HF}$ in aqueous solution by Johnson et al. [30] and the heat of formation of $\mathrm{CF}_{4}$ by Domalski and Armstrong [31]. General and critical reviews have been made by Benson [27], Kerr [28], and Lacher and Skinner [29].

The photoionization of the $\left(\mathrm{CF}_{3}\right)$ free radical has also been measured recently by Lifshitz and Chupka [32]. Thus it has seemed worthwhile to remeasure by photon impact the ionization energies of selected positive ions from several fluorocarbons. To assist in the interpretation of the results we include measurements of

\footnotetext{
*Work performed under the auspices of the International Atomic Energy Agency (Vienna, Austria) through the National Academy of Sciences (Washington, D.C.) and supported in part by the U.S. Atomic Energy Commission.

${ }^{* *}$ Guest worker, Institute for Materials Research, National Bureau of Standards, Washington, D.C. 20234. Permanent address: Comisión Nacional de Energía Atómica, Buenos Aires, Argentina.

Figures in brackets indicate the literature references at the end of this paper.
}

trifluoromethyl halides and fluoroform. All of these results are reported and discussed in this paper.

\section{Experimental Procedure}

Measurements were made by means of an instrument previously described [33]. It consists of a single focusing, $15 \mathrm{~cm}$ radius, 60 degree deflection mass spectrometer with a Seya-Namioka vacuum ultraviolet monochromator of a focal length of $1 \mathrm{~m}$ and a resolution of $1 \AA$ with both slits of the monochromator fixed at $0.1 \mathrm{~mm}$. The gold-coated 1200 groove $/ \mathrm{mm}$ grating could be manually rotated with a resetability better than $0.5 \AA$.

The wavelengths were measured with an accuracy better than $1 \AA$. The photon sources used were as follows:

1. From 1400 to $1050 \AA$ the continuum discharge in argon at a pressure of $400 \mathrm{~mm}$ excited by means of a $800 \mathrm{~W} 2450 \mathrm{MHz}$ microwave generator.

2. From approximately 1100 to $900 \AA$ the many-lined spectrum produced by microwave discharge in hydrogen.

3. From 950 to $600 \AA$ the Hopfield continuum excited by a d-c discharge in helium at a pressure of $250 \mathrm{~mm}$.

The relative photon intensity was measured by the photoelectric effect on a piece of chemically clean tungsten intercepting the beam of light when it leaves 
the ion source. A correction for the sensitivity of photon detection as a function of the wavelength was introduced according to Wheaton [34]. The ion current was measured with a 20 stage electron multiplier, a preamplifier, an amplifier, and scaler.

An empirical formula was established to correct for the decrease in the sample reservoir pressure, the molecular weight and the viscous flow of the gas through the leak. A program to permit all the above processing of the data by computer was written and used in most of this work.

A smoothing computational procedure using Chebyshev polynomials was also applied to some curves using a program developed at the NBS by R. B. Parlin, but all the ionization thresholds were determined before introducing any smoothing.

The gases used were obtained from commercial sources and purities, as stated by the suppliers, were generally better than 99.5 mole percent. Mass spectra indicated no interfering impurities significant to these measurements.

\section{Results}

Some typical photoionization yield curves for fluorocarbons and perfluoromethyl halides are shown in figures 1 to 5 . The wavelength is plotted in the abscissa and the ion yield (ion current per photon transmitted through the ion source) is plotted in arbitrary units on the ordinate.

Molecular ions were not observed in any of the fluorocarbons but they appeared in all the perfluoromethyl halides and in fluoroform. The $\mathrm{CF}_{3}^{+}$ions were the most abundant in all the molecules examined at a wavelength of $584 \AA$. The observed ionization thresholds of all ions are summarized in table 1.

$\mathbf{C F}_{3}^{+}$ion from $\mathbf{C F}_{4}$. The onset was located at $799 \pm 1 \AA$ in good agreement with that of $796.7 \AA$ found by Cook

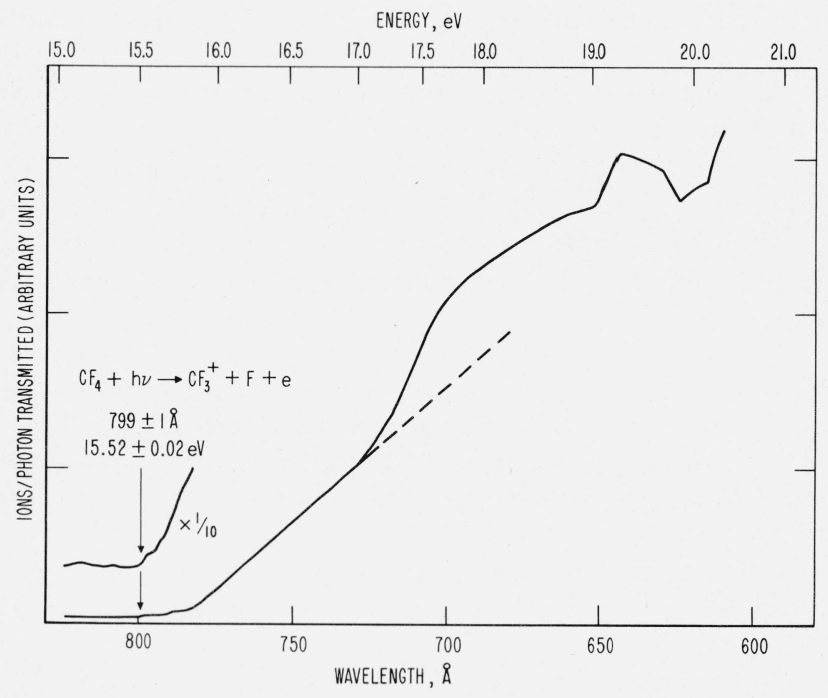

FigURE 1. Ionization curve for $\mathrm{CF}_{3}^{+}$ion from $\mathrm{CF}_{4}$. et al. [12]. It was gradual and smooth with no hot bands or autoionization peaks observed. The principal feature is a very definite increase in slope at approximately $725 \AA$ suggesting that at higher energies two ionization mechanisms are superimposed.

$\mathbf{C}_{2} \mathbf{F}_{5}^{+}$ion from $\mathbf{C}_{2} \mathbf{F}_{6}$. The onset is at $805 \AA$ and the curve is smooth and gradual until $720 \AA$. Then to 685 $\AA$ a partially resolved structure probably due to autoionization is observed and also another one near $650 \AA$.

$\mathbf{C F}_{3}^{+}$ion from $\mathbf{C}_{2} \mathbf{F}_{6}$. The threshold at $910 \AA$ is followed by a very long and continuous slope until $600 \AA$ with some structure superimposed near $730 \AA-690$ and $640 \AA$ probably due to some autoionization.

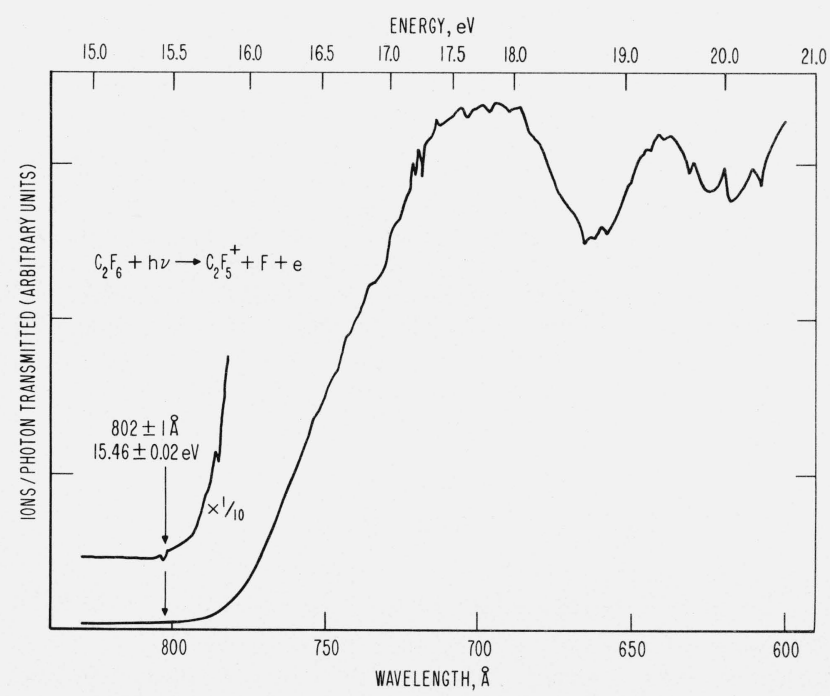

FIGURE 2. Ionization curve for $\mathrm{C}_{2} \mathrm{~F}_{5}^{+}$ion from $\mathrm{C}_{2} \mathrm{~F}_{6}$.

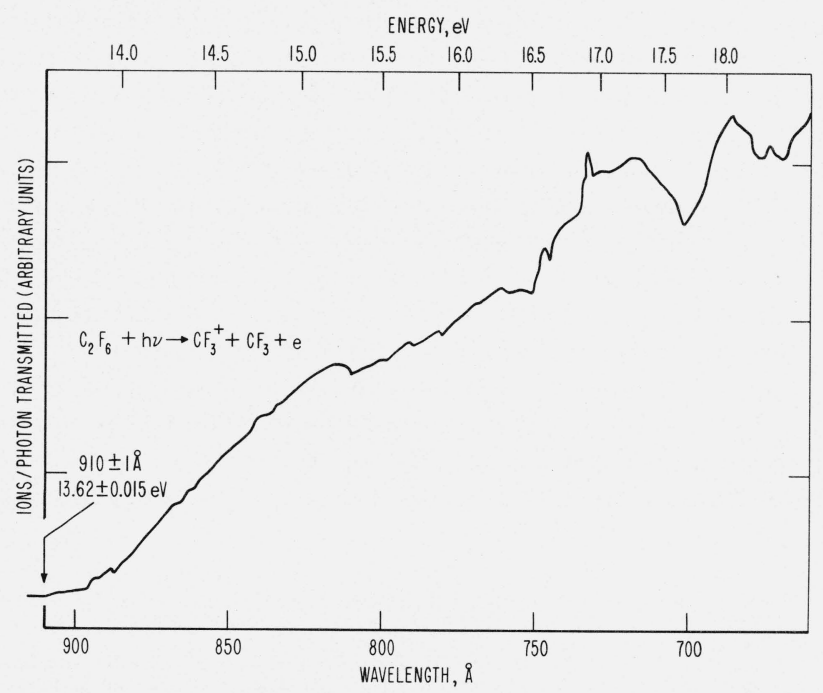

FigURE 3. Ionization curve for $\mathrm{CF}_{3}^{+}$ion from $\mathrm{C}_{2} \mathrm{~F}_{6}$. 


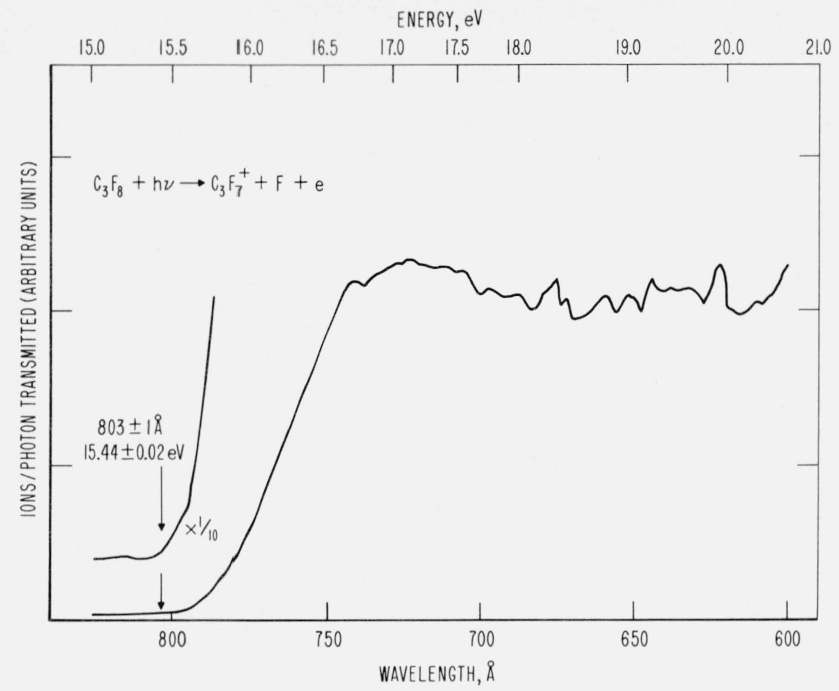

Figure 4. Ionization curve for $\mathrm{C}_{3} \mathrm{~F}_{7}^{+}$ion from $\mathrm{C}_{3} \mathrm{~F}_{8}$.

TABLE 1. Summary of experimental ionization thresholds

\begin{tabular}{|c|c|c|c|c|c|c|}
\hline Substance & Ion & $\AA$ & $\mathrm{eV}$ & $\mathrm{kJ} \mathrm{mol}^{-1}$ & kcal mol-1 & Observations \\
\hline \multirow[t]{2}{*}{$\mathrm{CF}_{4}$} & $\left\{\mathrm{CF}_{4}\right\}^{+}$ & & & & & No ions. \\
\hline & $\left(\left(\mathrm{C}_{2} \mathrm{~F}_{6}\right)^{+}\right.$ & & & & & \multirow[t]{3}{*}{ No ions. } \\
\hline \multirow[t]{2}{*}{$\mathrm{C}_{2} \mathrm{~F}_{6}$} & $\left\{\begin{array}{l}\left(\mathrm{C}_{2} \mathrm{~F}_{5}\right)^{+} \\
\left(\mathrm{CF}_{3}\right)^{+}\end{array}\right.$ & $\begin{array}{l}802 \\
910\end{array}$ & $\begin{array}{l}15.46 \\
13.62\end{array}$ & $\begin{array}{l}1492 \\
1314\end{array}$ & $\begin{array}{l}356.5 \\
314.1\end{array}$ & \\
\hline & $(\mathrm{CF})^{+}$ & 740 & $\begin{array}{l}10.02 \\
16.75\end{array}$ & 1616 & $\begin{array}{l}386.1 \\
386.3\end{array}$ & \\
\hline \multirow{3}{*}{$\mathrm{C}_{3} \mathrm{~F}_{8}$} & $\left\{\begin{array}{l}\left(\mathrm{C}_{3} \mathrm{~F}_{8}\right)^{+} \\
\left(\mathrm{C}_{3} \mathrm{~F}_{7}\right)^{+}\end{array}\right.$ & 803 & 15.44 & 1490 & & \multirow[t]{3}{*}{ No ions. } \\
\hline & $\left\{\begin{array}{l}\left(\mathrm{C}_{2}^{3} \mathrm{~F}_{5}\right)^{+} \\
\left(x^{2}\right.\end{array}\right.$ & $\begin{array}{l}000 \\
931\end{array}$ & $\begin{array}{l}13.44 \\
13.32\end{array}$ & 1285 & $\begin{array}{l}350.1 \\
307.2\end{array}$ & \\
\hline & $\left(\mathrm{CF}_{3}\right)^{+}$ & 938 & 13.22 & 1276 & 304.9 & \\
\hline \multirow{6}{*}{$\mathrm{C}_{4} \mathrm{~F}_{10}$} & $\left(\left(\mathrm{C}_{\mathrm{F}} \mathrm{F}_{10}\right)^{+}\right.$ & & & & & \multirow[t]{8}{*}{ No ions. } \\
\hline & & 804 & 15.42 & 1488 & 355.6 & \\
\hline & $\left(\mathrm{C}_{3} \mathrm{~F}_{5}\right)^{+}$ & $\begin{array}{l}932 \\
792\end{array}$ & $\begin{array}{l}13.30 \\
15.65\end{array}$ & $\begin{array}{l}1283 \\
1510\end{array}$ & $\begin{array}{l}306.7 \\
360.9\end{array}$ & \\
\hline & $\left(\mathrm{C}_{2} \mathrm{~F}_{5}\right)^{+}$ & 950 & 13.05 & 1259 & 300.9 & \\
\hline & $\left(\mathrm{C}_{2} \mathrm{~F}_{3}\right)^{+}$ & 792 & 15.65 & 1510 & 360.9 & \\
\hline & $\left(\mathrm{CF}_{3}\right)^{+}$ & 938 & 13.22 & 1276 & 304.9 & \\
\hline \multirow[t]{2}{*}{$\mathrm{CF}_{3} \mathrm{Cl}$} & $\left\{\left(\mathrm{CF}_{3} \mathrm{Cl}\right)^{+}\right.$ & 1001 & 12.43 & 1199 & 286.8 & \\
\hline & $\left(\mathrm{l} F_{3}\right)^{+}$ & 982 & 12.57 & 1213 & 290.0 & \\
\hline $\mathrm{CF}_{3} \mathrm{Br}$ & $\int\left(\mathrm{CF}_{3} \mathrm{Br}\right)^{+}$ & Detected & $t$ not meas & ured. & & \multirow{3}{*}{ Small peak. } \\
\hline & & 1059 & 11.84 & 1142 & 273.0 & \\
\hline $\mathrm{CF}_{3} \mathrm{I}$ & $\left\{\left(\mathrm{CF}_{3} \mathrm{I}\right)^{+}\right.$ & 1212 & 10.23 & 987 & 236.0 & \\
\hline & & & & & & \\
\hline $\mathrm{CF}_{3} \mathrm{H}$ & 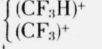 & $\begin{array}{l}\text { Detected } \\
\quad 877\end{array}$ & t not meas & 1364 & 326.1 & Small peak. \\
\hline
\end{tabular}

In this and subsequent tables and text, the following equivalences are used: $1 \mathrm{eV}$ molecule $^{-1}=96.4870 \mathrm{~kJ} \mathrm{~mol}^{-1} ; 1 \mathrm{kcal} \mathrm{mol} \mathrm{m}^{-1}=4.1840 \mathrm{~kJ} \mathrm{~mol}^{-1} ; 1 \mathrm{~cm}^{-1}=12398.1 \times 10^{-8} \mathrm{eV}$.

$\mathbf{C}_{3} \mathbf{F}_{7}^{+}$ion from $\mathbf{C}_{3} \mathbf{F}_{8}$. The curve begins at $803 \AA$ and increases gradually until nearly $745 \AA$ (the onset of the $\mathrm{CF}^{+}$ion) where it reaches a flat top.

$\mathbf{C F}_{3}^{+}$from $\mathbf{C F}_{3} \mathbf{I}$. The onset is very gradual and difficult to locate exactly, but definitely at an energy not higher than $10.89 \mathrm{eV}$. Some structure in the curve (probably due to vibrations in the ion) could be clearly seen when a correction for the scattered light was introduced.

The curves of the remaining ions also exhibit smooth thresholds followed by more or less gradual increases.

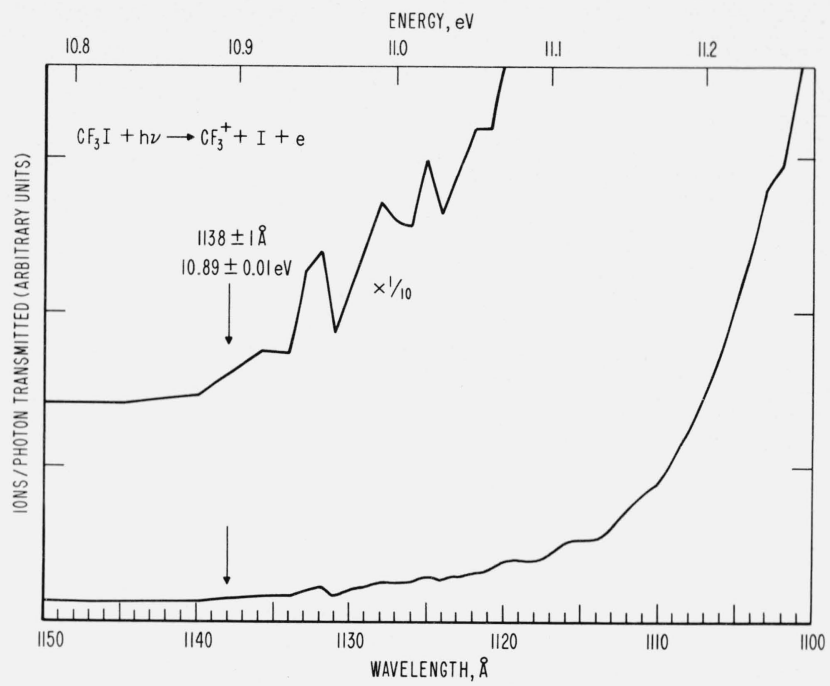

FIGURE 5. Ionization curve for $\mathrm{CF}_{3}^{+}$ion from $\mathrm{CF}_{3} \mathrm{I}$.

Occasionally a rapid increase is observed which is interpreted as the beginning of a new dissociation process. No other special characteristics were observed of consequence for this work. It is noteworthy that in these molecules as in the case of hydrocarbon ions [35] little evidence is obtained for autoionization except as noted above.

\section{Discussion}

The values at room temperature of the heat of formation $\Delta H f_{298}^{\circ}\left(\mathrm{CF}_{3} \mathrm{X}\right)$ and the heat of dissociation $\mathrm{D}_{298}\left(\mathrm{CF}_{3}-\mathrm{X}\right)$ for $\mathrm{X}=\mathrm{F}, \mathrm{Cl}, \mathrm{Br}, \mathrm{I}, \mathrm{H}$ and $\mathrm{CF}_{3}$ are known. Thus it is possible to derive in each case a value for the heat of formation $\Delta H f_{298}^{\circ}\left(\mathrm{CF}_{3}\right)$ of the free radical by the relation

$\Delta H f_{298}^{\circ}\left(\mathrm{CF}_{3}\right)=\Delta H f_{298}^{\circ}\left(\mathrm{CF}_{3}-\mathrm{X}\right)$

$$
+\mathrm{D}_{298}\left(\mathrm{CF}_{3}-\mathrm{X}\right)-\Delta H f_{298}^{\circ}(\mathrm{X}) .
$$

The values of $\Delta H f_{0}^{\circ}\left(\mathrm{CF}_{3} \mathrm{X}\right)$ were calculated using the values of $H_{298}-H_{0}$ given in NBS Technical Note 270-3 [14]. Calling $\left(\mathrm{CF}_{3}^{*}\right)^{+}$the ions, excited or not, in the state and with all the excess energy with which they are obtained by photoionization at the threshold, we have calculated:

$$
\Delta H f_{0}^{\circ}\left(\mathrm{CF}_{3}^{*}\right)^{+}=\Delta H f_{0}^{\circ}\left(\mathrm{CF}_{3} \mathrm{X}\right)+\mathrm{A}\left(\mathrm{CF}_{3}^{*}\right)-\Delta H f_{0}^{\circ}(\mathrm{X})
$$

In the case of the free radical $\mathrm{CF}_{3}$ the value ${ }^{2}$ $\Delta H f_{298}^{\circ}\left(\mathrm{CF}_{3}\right)=-112.5 \mathrm{kcal} \mathrm{mol}^{-1}$ has been obtained by averaging the other six numbers in that column in table 2 ; it coincides with the value $-112.5 \pm 1.2 \mathrm{kcal}$ mol-1 $^{-1}$ measured by Coomber and Whittle [21]. The

\footnotetext{
${ }^{2}$ The use of units of $\mathrm{kcal} \mathrm{mol}^{-1}$ in portions of this paper is for the purpose of comparing present results with previously published data.
} 
TABLE 2a. Thermodynamic values (in $\mathrm{kcal} \mathrm{mol}^{-1}$ ) of several fluorocarbons ${ }^{\text {a }}$

\begin{tabular}{|c|c|c|c|c|c|c|c|c|c|c|}
\hline$\Delta H f_{298}^{\circ}$ & $\left(\mathrm{CF}_{3} \mathrm{X}\right)$ & Ref. ${ }^{b}$ & $\Delta H f_{0}^{\circ}\left(\mathrm{CF}_{3} \mathrm{X}\right)^{\mathrm{c}}$ & $\mathrm{D}_{298}\left(\mathrm{CF}_{3}-\mathrm{X}\right)$ & Ref. $^{b}$ & $\mathrm{~A}\left(\mathrm{CF}_{3}^{*}\right)$ & $\Delta H f_{298}^{\circ}\left(\mathrm{CF}_{3}\right)$ & $\Delta H f_{0}^{\circ}\left(\mathrm{CF}_{3}^{*}\right)^{+}$ & E.E. & $\mathrm{I}\left(\mathrm{CF}_{3}^{*}\right)^{+\mathrm{f}}$ \\
\hline $\begin{array}{l}\mathrm{CF}_{3}-\mathrm{F} \\
\mathrm{CF}_{3}-\mathrm{H} \\
\mathrm{CF}_{3}-\mathrm{CF}_{3} \\
\mathrm{CF}_{3} \\
\mathrm{CF}_{3}-\mathrm{Cl} \\
\mathrm{CF}_{3}-\mathrm{Br} \\
\mathrm{CF}_{3}-\mathrm{I}\end{array}$ & $\begin{array}{l}-222.87 \pm 0.38 \\
-165.1 \pm 0.5 \\
-321.0 \pm 0.1 \\
-165.8 \pm 0.5 \\
-155.5 \pm 0.2 \\
-139.4\end{array}$ & $\begin{array}{c}{[31]} \\
{[24]} \\
{[22]} \\
{[23]} \\
{[19-20]} \\
{[24]}\end{array}$ & $\begin{array}{l}-221.5 \pm 0.4 \\
-163.4 \pm 0.5 \\
-319.0 \pm 0.1 \\
-111.5 \\
-164.6 \pm 0.5 \\
-152.6 \pm 0.2 \\
-138.0\end{array}$ & $\begin{array}{l}129.3 \pm 2 \\
106.2 \pm 0.5 \\
93 \pm 4 \\
\quad 1 \\
82.9 \\
69.4 \pm 0.8 \\
53.7\end{array}$ & $\begin{array}{l}21 \\
25 \\
18 \\
\\
(\mathrm{e}) \\
20 \\
24\end{array}$ & $\begin{array}{l}357.9 \\
326.1 \\
314.1\end{array}$ & $\begin{array}{l}-112.45 \\
-111.0 \\
-114.0 \\
\mathrm{~d}-112.5 \\
-112.0 \\
-112.8 \\
-111.3\end{array}$ & $\begin{array}{l}118.0 \\
109.6 \\
106.6 \\
101.8 \\
96.7 \\
92.2 \\
87.3\end{array}$ & $\begin{array}{l}>30.7 \\
>21.8 \\
>19.3 \\
>14.5 \\
>9.4 \\
>4.9 \\
>0.0\end{array}$ & $\begin{array}{r}229.5 \\
220.6 \\
218.1 \\
{ }^{*} 213.3 \\
208.2 \\
203.7 \\
198.8\end{array}$ \\
\hline
\end{tabular}

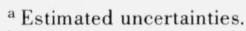

${ }^{\mathrm{b}}$ Refers to numbers in the bibliography.

c Calculated from $\Delta H f_{298}^{\circ}$

d Average of the other six values in this column.

e Calculated from $\mathrm{CF}_{3} \mathrm{Br}$ and $\mathrm{CF}_{3} \mathrm{I}$.

${ }^{f}$ Calculated from E.E. $+\Delta H f_{0}^{\circ}\left(\mathrm{CF}_{3}^{*}\right)+$ from $\mathrm{CF}_{3} \mathrm{I}$

${ }^{g}$ Obtained by Lifschitz and Chupka [32] by photoionization of $\mathrm{CF}_{3}$ free radical.

TABLE 2b. Thermodynamical values in $\mathrm{kJ} \mathrm{mol}^{-1}$ for the same compounds

\begin{tabular}{l|r|r|r|r|r|r|r|r}
\hline \hline \multicolumn{1}{c|}{$\Delta f_{298}^{\circ}$} & $\left(\mathrm{CF}_{3} \mathrm{X}\right)$ & $\Delta H f_{0}^{\circ}\left(\mathrm{CF}_{3} \mathrm{X}\right)$ & $\mathrm{D}_{298}\left(\mathrm{CF}_{3}-\mathrm{X}\right)$ & \multicolumn{1}{c|}{$\mathrm{A}\left(\mathrm{CF}_{3}^{*}\right)$} & $\Delta H f_{298}^{\circ}\left(\mathrm{CF}_{3}\right)$ & $\Delta H f_{0}^{\circ}\left(\mathrm{CF}_{3}^{*}\right)$ & \multicolumn{1}{c}{ E.E. } & \multicolumn{1}{c}{$\mathrm{I}\left(\mathrm{CF}_{3}^{*}\right)^{+}$} \\
\hline & & & & & & & \\
$\mathrm{CF}_{3}-\mathrm{F}$ & -956.9 & -926.8 & 541.0 & 1497.5 & -470.5 & 493.7 & $>128.4$ & 960.2 \\
$\mathrm{CF}_{3}-\mathrm{H}$ & -697.0 & -683.7 & 44.0 & 1364.4 & -464.4 & 458.6 & $>91.2$ & 923.0 \\
$\mathrm{CF}_{3}-\mathrm{CF}_{3}$ & -1343.0 & -1334.0 & 389.0 & 1314.2 & -477.0 & 44.0 & $>80.8$ & 912.5 \\
$\mathrm{CF}_{3}$ & -466.5 & 346.8 & 1213.4 & -470.7 & 425.9 & $>60.7$ & 892.5 \\
$\mathrm{CF}_{3}-\mathrm{Cl}$ & -693.7 & -688.7 & -468.6 & 404.6 & $>39.3$ & 871.1 \\
$\mathrm{CF}_{3}-\mathrm{Br}$ & -650.6 & -638.5 & 290.4 & 1142.2 & -472.0 & 385.8 & $>20.5$ & 852.3 \\
$\mathrm{CF}_{3}-\mathrm{I}$ & -583.7 & -577.8 & 224.7 & 1050.2 & -465.7 & 365.3 & $>0.0$ & 831.8 \\
\hline
\end{tabular}

corresponding $\Delta H f_{0}^{\circ}\left(\mathrm{CF}_{3}^{*}\right)^{+}$was obtained by correcting to $0 \mathrm{~K}$ and adding the threshold photoionization energy of $9.5 \mathrm{eV}=213.3 \mathrm{kcal} \mathrm{mol}^{-1}$ measured by Lifschitz and Chupka [32].

From the comparison of the $\Delta H f_{298}^{\circ}\left(\mathrm{CF}_{3}\right)$ values so obtained it is easy to see that the thermochemical values agree quite well; their differences are not larger than $\pm 1.5 \mathrm{kcal} \mathrm{mol}^{-1}$. On the contrary the differences in $\Delta H f_{0}^{\circ}\left(\mathrm{CF}_{3}^{*}\right)^{+}$are much larger, some 30 kcal mol ${ }^{-1}$ from $\mathrm{CF}_{4}$ to $\mathrm{CF}_{3} \mathrm{I}$. The disagreement is too large to be attributed to the errors in either the photoionization or the thermochemical measurements. It is apparent that for some reason we have not measured the adiabatic potential and some excess energy is included (perhaps very small for $\mathrm{CF}_{3} \mathrm{I}$ ).

The substances in table 2 have been listed according to their decreasing values of $\Delta H f_{0}^{\circ}\left(\mathrm{CF}_{3}^{*}\right)^{+}$. We observe that the order is one of increasing atomic weight of $\mathrm{X}$ and of increasing $\mathrm{C}-\mathrm{X}$ distances [36] for the halides. This suggests the following explanation. In all the listed $\mathrm{CF}_{3} \mathrm{X}$ molecules the orbitals of the valence electrons of the carbon are $s p^{3}$. It has been demonstrated [26] that the $\mathrm{CF}_{3}$ free radical is not planar. That suggests that the orbitals retain at least some $s p^{3}$ character. However, the $\mathrm{CF}_{3}^{+}$ion is planar, and the three valence electrons are in $s p^{2}$ orbitals lying in a plane with the vacant $p$ orbital perpendicular to it [37]. It seems reasonable then to assume that, like the isoelectronic $\mathrm{BF}_{3}$ molecule, an electron from one of the nonbonding pairs of an $\mathrm{F}$ jumps to the $p-\mathrm{C}$ orbital forming a $\pi$ bonding. There are three similar possible configurations in resonance with the empty $p$ orbital structure and with some partially ionic structures [38]. In the case of $\mathrm{BF}_{3}$ a resonance energy of $48 \mathrm{kcal} \mathrm{mol}^{-1}$ has been calculated [39]. It is likely that in the $\mathrm{CF}_{3}^{+}$ion due to more favorable charge distribution conditions that value will be still higher.

The following consequences can be deduced:

If we accept the approximate value of $10.8 \mathrm{eV}$ suggested by Lifschitz and Chupka as the vertical ionization potential of the $\mathrm{CF}_{3}$ free radical, an adiabatic threshold energy lower than $8.62 \mathrm{eV}$ (as our measurements from $\mathrm{CF}_{3} \mathrm{I}$ suggest) does not seem unreasonable but very probable. This would require that both the FCF angles and the FC distances in the free radical be approximately the same as those in the $\mathrm{CF}_{3} \mathrm{X}$ molecules; in other words that the $\mathrm{C}$ orbitals be still nearly pure $s p^{3}$.

If the $\mathrm{B}-\mathrm{F}$ distances change from $1.43 \mathrm{~A}$ in the $\mathrm{BF}_{4}^{-}$to $1.295 \AA$ in $\mathrm{BF}_{3}$ because of the resonance of the $\pi$ bonding and especially because of that of the partially ionic forms $[38,41]$, similar and perhaps larger changes can be expected from $\mathrm{CF}_{3}$ radical to $\mathrm{CF}_{3}^{+}$ion. Thus some appreciable amount of energy must be associated with the symmetrical stretching vibrations. Of course large out-of-plane bending vibrations are also expected.

It is likely that in the case of the $\mathrm{CF}_{3} \mathrm{X}$ molecules, at least part of the resonance energy is not lost as excess energy but transferred by radiationless mechanisms to the dissociation coordinate in accordance with the fundamental postulate of the quasiequilibrium theory of mass spectra [40]. In that case the changes in orbital configurations, the $\pi$ bonding and the res- 
onance, occur at least partially before the dissociation is completed. Palko and Drury have suggested that the formation of the $\pi$ orbitals in $\mathbf{B F}_{3}$ is due to the high repulsion between the nonbonding electron pairs crowded in the small valence shell of the $\mathrm{F}$ atoms. Thus it can be expected that the process will be rather difficult to complete in $\mathrm{CF}_{3} \mathrm{X}$ before dissociation when the $\mathrm{X}$ atom is $\mathrm{F}$, easier when it is $\mathrm{Cl}$ and $\mathrm{Br}$, and still easier with I.

Despite the fact that $\mathrm{CF}_{3} \mathrm{I}^{+}$has a longer residence time in the ion source than $\mathrm{CF}_{3} \mathrm{Br}^{+}$, the molecular ion peak is relatively larger. No molecular or corresponding metastable peak is observed with $\mathrm{CF}_{4}$. This indicates that the dissociation process is the longest with $\mathrm{CF}_{3} \mathrm{I}$, shorter in $\mathrm{CF}_{3} \mathrm{Br}$ and $\mathrm{CF}_{3} \mathrm{Cl}$, and so short in $\mathrm{CF}_{4}$ that it is not improbable that some appreciable kinetic energy could be lost in the fragmentation.

Thus in the $\mathrm{CF}_{3} \mathrm{I}$ the dissociation process gives more time and far less difficulty to the transfer of the resonance energy to the dissociation coordinate; this is enough for the transfer to be total or nearly so. In the rapid dissociation of the $\mathrm{CF}_{4}$ only a small amount can be transferred, the other part being lost as excess energy. Similar reasoning would explain the intermediate situation in the dissociation of $\mathrm{CF}_{3}-\mathrm{Cl}$, $\mathrm{CF}_{3}-\mathrm{Br}$, and also with the nonhalogens like $\mathrm{CF}_{3}-\mathrm{H}$ and $\mathrm{CF}_{3}-\mathrm{CF}_{3}$, etc. The decisive influence of the crowding of electrons in the valence shell of $\mathrm{F}$ and $\mathrm{X}$ could explain why the nontransferred excess energy is so definitely dependent on the nature of the atoms related to the bond broken in those molecules, as we will see later.

In the case of the $\mathrm{CF}_{3}$ free radical there is no fragmentation and thus below the vertical ionization potential the transfer of excess energy to the ionization process must be reached through a completely different mechanism. Thus only in this case vibrational peaks appear clearly superimposed on the threshold of the ionization yield curve. Apparently only the outof-plane bending frequencies are observed on the curves obtained by Lifshitz and Chupka.

This does not need to be interpreted in the sense that there are not other vibrations in the ion but only as an evidence that this is the only one which has a transfer mechanism rapid enough or efficient enough to be detected.

This could explain the inability to observe the true adiabatic threshold energy. The difference between the adiabatic and the observed value would correspond at least to some energy of the completely symmetrical stretching vibrations.

The smallest excess of energy is that of $\mathrm{D}\left(\mathrm{CF}_{3}-\mathrm{I}\right)$, but we have not found any indication that it is zero or very small, so we can calculate only lower limits of the excesses of energy (table 3 ;

It has been suggested above that the excess energy would only depend on the bond broken. We can effectively observe from table 1 that for the $\mathrm{CF}_{3}^{+}$ions obtained from $\mathrm{C}_{3} \mathrm{~F}_{8}$ and $\mathrm{C}_{4} \mathrm{~F}_{10}$, in both of which we obtain the same ion by breaking similar bonds, where the only probable difference is a difference in excess
TABLE 3. Lower limits of excess energy calculated from threshold energies

\begin{tabular}{|c|c|c|c|}
\hline \multirow{2}{*}{ Bond dissociation } & \multicolumn{3}{|c|}{ Excess energy } \\
\hline & $\mathrm{kcal} \mathrm{mol}^{-1}$ & $\mathrm{~kJ} \mathrm{~mol}^{-1}$ & $\mathrm{eV}$ \\
\hline $\mathrm{D}\left(\mathrm{CF}_{3}-\mathrm{F}\right) \ldots$ & $>30.7$ & $>128$ & $>1.32$ \\
\hline $\mathrm{D}\left(\mathrm{CF}_{3}-\mathrm{H}\right) \ldots \ldots$ & $>22.3$ & $>93$ & $>0.96$ \\
\hline $\mathrm{D}\left(\mathrm{CF}_{3}-\mathrm{CF}_{3}\right) \ldots \ldots$ & $>19.3$ & $>81$ & $>0.83$ \\
\hline $\mathrm{I}\left(\mathrm{CF}_{3}\right) \ldots \ldots \ldots \ldots$ & $>14.5$ & $>61$ & $>0.63$ \\
\hline $\mathrm{D}\left(\mathrm{CF}_{3}-\mathrm{Cl}\right) \ldots$ & $>9.4$ & $>39$ & $>0.41$ \\
\hline $\mathrm{D}\left(\mathrm{CF}_{3}-\mathrm{Br}\right) \ldots$ & $>4.9$ & $>20$ & $>0.21$ \\
\hline $\mathrm{D}\left(\mathrm{CF}_{3}-\mathrm{I}\right) \ldots \ldots$ & $>0.0$ & $>0$ & $>0.00$ \\
\hline
\end{tabular}

energy, this difference is exactly zero. However, in the case of the $\mathrm{C}_{2} \mathrm{~F}_{5}^{+}$ions obtained from $\mathrm{C}_{2} \mathrm{~F}_{6}$ and $\mathrm{C}_{3} \mathrm{~F}_{7}$, in which different bonds are broken, the difference is $2.14 \mathrm{eV}$. Further, in the case of the $\mathrm{C}_{3} \mathrm{~F}_{7}^{+}$ions obtained from $\mathrm{C}_{3} \mathrm{~F}_{8}$ and $\mathrm{C}_{4} \mathrm{~F}_{10}$, in which the same two kinds of bonds are broken, the difference is also $2.14 \mathrm{eV}$.

Comparing the threshold energies of $\mathrm{CF}_{3}^{+}$and $\mathrm{C}_{2} \mathrm{~F}_{5}^{+}$from $\mathrm{C}_{3} \mathrm{~F}_{8}$, and assuming the same excess energy because the same bond is broken, we get

$$
I\left(\mathrm{C}_{2} \mathrm{~F}_{5}\right)^{+}=I\left(\mathrm{CF}_{3}\right)^{+}+0.10 \mathrm{eV}
$$

from $\mathrm{CF}_{3}^{+}$and $\mathrm{C}_{3} \mathrm{~F}_{7}^{+}$(from $\mathrm{C}_{4} \mathrm{~F}_{10}$ )

$$
I\left(\mathrm{C}_{3} \mathrm{~F}_{7}\right)^{+}=I\left(\mathrm{CF}_{3}\right)^{+}+0.08 \mathrm{eV}
$$

$$
\text { by difference: } I\left(\mathrm{C}_{2} \mathrm{~F}_{5}^{+}\right)-I\left(\mathrm{C}_{3} \mathrm{~F}_{7}\right)^{+}=0.02 \mathrm{eV} \text {. }
$$

This is exactly the difference between the threshold energies of the $\left(\mathrm{C}_{2} \mathrm{~F}_{5}\right)^{+}$from $\mathrm{C}_{2} \mathrm{~F}_{6}$ and $\left(\mathrm{C}_{3} \mathrm{~F}_{7}\right)^{+}$from $\mathrm{C}_{3} \mathrm{~F}_{8}$.

The difference of $0.40 \mathrm{eV}$ between threshold energies of $\mathrm{CF}_{3}^{+}$from $\mathrm{C}_{2} \mathrm{~F}_{6}$ and from $\mathrm{C}_{3} \mathrm{~F}_{8}$ is easily explained by the fact that in the first case a bond between two primary carbons is broken whereas in the second one it is a bond between a primary and a secondary carbon. The difference of $0.27 \mathrm{eV}$ between the threshold energy of $\left(\mathrm{C}_{2} \mathrm{~F}_{5}\right)^{+}$from $\mathrm{C}_{3} \mathrm{~F}_{8}$ and $\mathrm{C}_{4} \mathrm{~F}_{10}$ would likewise be due to the fact that one bond is between a primary and a secondary carbon and the other between two secondary carbons.

There probably are small differences in the excess energy related to each kind of bond and so the differences observed do not necessarily measure accurately the differences in bond energies. As a rule, the internal consistency of the values obtained by photoionization is not a proof in itself that the differences in threshold energies can give accurately the differences in bond dissociation energies. Nevertheless in this case if we note that the difference in the appearance potentials of the $\left(\mathrm{CF}_{3}\right)^{+}$ions from $\mathrm{CF}_{4}$ and $\mathrm{C}_{2} \mathrm{~F}_{6}$ is $43.8 \mathrm{kcal}$ $\mathrm{mol}^{-1}$ but the calculated difference in excess energy is only $8.4 \mathrm{kcal} \mathrm{mol}^{-1}$ (less than one fifth) it seems probable that the differences in excess energy are small between bonds connecting the same kinds of atoms (all $\mathrm{C}-\mathrm{C}$ or all $\mathrm{C}-\mathrm{F}$ ) but differing only in the fact that the carbons are primary or secondary. When the total differences are small themselves, they can 
be taken to good approximation as differences in bond dissociation energies, perhaps with not less accuracy than direct thermochemical measurements.

In our case we can write approximately $\mathrm{D}\left(\mathrm{C}_{1}-\mathrm{C}_{1}\right)-$ $0.4 \mathrm{eV} \simeq \mathrm{D}\left(\mathrm{C}_{1}-\mathrm{C}_{2}\right) \simeq \mathrm{D}\left(\mathrm{C}_{2}-\mathrm{C}_{2}\right)+0.3 \mathrm{eV}$ and consider that to a good approximation all the m-19 ions measured had the same excess energy $A$ and all the others. an excess $B \simeq A-8.4 \mathrm{kcal} \mathrm{mol}^{-1}$, despite the fact that the values obtained from $\mathrm{CF}_{3} \mathrm{I}$ indicate that $B \geqslant 19.3 \mathrm{kcal} \mathrm{mol}{ }^{-1}$ which is a rather large value.

If we accept the values

$$
\begin{aligned}
& I\left(\mathrm{CF}_{3}\right)^{+} \leqslant 8.62 \mathrm{eV} \simeq 198.8 \mathrm{kcal} \mathrm{mol}^{-1} \text { and } \\
& \Delta H f^{\circ}\left(\mathrm{CF}_{3}\right)^{+} \leqslant+87.3 \mathrm{kcal} \mathrm{mol}{ }^{-1} \text { we get } \\
& I\left(\mathrm{C}_{2} \mathrm{~F}_{5}\right)^{+}=I\left(\mathrm{CF}_{3}\right)^{+}+0.10 \mathrm{eV} \leqslant 8.72 \mathrm{eV} \\
& I\left(\mathrm{C}_{3} \mathrm{~F}_{7}\right)^{+}=I\left(\mathrm{CF}_{3}\right)^{+}+0.08 \mathrm{eV} \leqslant 8.70 \mathrm{eV} \\
& I\left(\mathrm{C}_{4} \mathrm{~F}_{9}\right)^{+}=I\left(\mathrm{C}_{3} \mathrm{~F}_{7}\right)^{+}-0.02 \mathrm{eV} \leqslant 8.68 \mathrm{eV}
\end{aligned}
$$

Accepting the mean value

$$
\begin{aligned}
& \Delta H f_{298}^{\circ}\left(\mathrm{CF}_{3}\right)=-112.5 \pm 0.4 \mathrm{kcal} \mathrm{mol}^{-1} \text { we get } \\
& \mathrm{D}_{298}\left(\mathrm{CF}_{3}-\mathrm{CF}_{3}\right)=96.0 \pm 0.5 \mathrm{kcal} \mathrm{mol}^{-1} \text { and } \\
& \mathrm{D}_{298}\left(\mathrm{CF}_{3}-\mathrm{F}\right)-\mathrm{D}_{298}\left(\mathrm{CF}_{3}-\mathrm{CF}_{3}\right) \\
& =33.3 \mathrm{kcal} \mathrm{mol}{ }^{-1}=1.44 \mathrm{eV} .
\end{aligned}
$$

Thus this CF bond is approximately $1.44 \mathrm{eV}$ stronger than the $\mathrm{C}-\mathrm{C}$ bonds between primary carbons.

Less accurately we can write:

$$
\begin{aligned}
\mathrm{D}_{298}\left(\mathrm{C}_{1}-\mathrm{C}_{2}\right) & \simeq \mathrm{D}_{298}\left(\mathrm{C}_{1}-\mathrm{C}_{1}\right) \\
& -0.40 \mathrm{eV}=86.8 \mathrm{kcal} \mathrm{mol}^{-1} \\
\mathrm{D}_{298}\left(\mathrm{C}_{2}-\mathrm{C}_{2}\right) \simeq & \mathrm{D}_{298}\left(\mathrm{C}_{1}-\mathrm{C}_{1}\right) \\
& -0.67 \mathrm{eV}=80.6 \mathrm{kcal} \mathrm{mol}^{-1} .
\end{aligned}
$$

It is thus possible to predict the following values for the appearance potentials from $\mathrm{C}_{5} \mathrm{~F}_{12}$.

$$
\begin{array}{ll}
\mathrm{A}\left(\mathrm{C}_{5} \mathrm{~F}_{11}\right)^{+}=15.4 \mathrm{eV} & \mathrm{A}\left(\mathrm{C}_{2} \mathrm{~F}_{5}\right)^{+}=13.0 \mathrm{eV} \\
\mathrm{A}\left(\mathrm{C}_{4} \mathrm{~F}_{9}\right)^{+}=13.3 \mathrm{eV} & \mathrm{A}\left(\mathrm{CF}_{3}\right)^{+}=13.2 \mathrm{eV} \\
\mathrm{A}\left(\mathrm{C}_{3} \mathrm{~F}_{7}\right)^{+}=13.0 \mathrm{eV} & I\left(\mathrm{C}_{5} \mathrm{~F}_{11}\right)^{+} \leqslant 8.68 \mathrm{eV}
\end{array}
$$

Assuming for all the $\mathrm{C}_{1}-\mathrm{F}$ dissociations the same excess energy of $30.7 \mathrm{kcal} \mathrm{mol}^{-1}$ found for $\mathrm{D}\left(\mathrm{CF}_{3}-\mathrm{F}\right)$ we can obtain

$$
\begin{aligned}
& \mathrm{D}\left(\mathrm{C}_{2} \mathrm{~F}_{5}-\mathrm{F}\right)=125.8 \mathrm{kcal} \mathrm{mol}^{-1} \\
& \mathrm{D}\left(\mathrm{C}_{3} \mathrm{~F}_{7}-\mathrm{F}\right)=125.6 \mathrm{kcal} \mathrm{mol}^{-1} .
\end{aligned}
$$

This coincidence suggests that in the second case the lost $\mathrm{F}$ was also bonded to a primary carbon and we can accept a mean value

$$
\mathrm{D}\left(\mathrm{C}_{1}-\mathrm{F}\right)=125.7 \mathrm{kcal} \mathrm{mol}^{-1},
$$

slightly lower than $\mathrm{D}\left(\mathrm{F}_{3} \mathrm{C}-\mathrm{F}\right)$. This result can be compared with

$$
\begin{aligned}
& \mathrm{D}\left(\mathrm{CF}_{3}-\mathrm{Br}\right)=69.4 \pm 0.8 \mathrm{kcal} \mathrm{mol}^{-1} \\
& \mathrm{D}\left(\mathrm{C}_{2} \mathrm{~F}_{5}-\mathrm{Br}\right)=\mathrm{D}\left(\mathrm{C}_{3} \mathrm{~F}_{7}-\mathrm{Br}\right) \\
& =67.0 \pm 2.5 \mathrm{kcal} \mathrm{mol} \mathrm{mol}^{-1}
\end{aligned}
$$

obtained by Coomber and Whittle [2]. If in the second case $\mathrm{F}$ were bonded to the secondary carbon, that would have meant $\mathrm{D}\left(\mathrm{C}_{1}-\mathrm{F}\right)=D\left(C_{2}-\mathrm{F}\right)$. This does not seem likely. The value obtained for $\Delta H f_{298}^{\circ}\left(\mathrm{CF}_{3}\right)$ from $\mathrm{C}_{2} \mathrm{~F}_{6}$ appears to be too high, and that from $\mathrm{CF}_{3} \mathrm{I}$ too low. It is likely that:

$$
\begin{aligned}
& \mathrm{D}\left(\mathrm{CF}_{3}-\mathrm{CF}_{3}\right)=96.0 \pm 0.5 \mathrm{kcal} \mathrm{mol}^{-1} \\
& \mathrm{D}\left(\mathrm{CF}_{3}-\mathrm{Br}\right)=69.7 \pm 1 \mathrm{kcal} \mathrm{mol}^{-1} \\
& \mathrm{D}\left(\mathrm{CF}_{3}-\mathrm{I}\right)=52.5 \pm 1 \mathrm{kcal} \mathrm{mol}^{-1}
\end{aligned}
$$

Table 4 has been obtained using these values.

We can also mention that except for $\mathrm{CF}_{3}-\mathrm{F}$, the $\mathrm{C}_{1}-\mathrm{F}$ bonds are $\mathrm{D}_{298}\left(\mathrm{C}_{1}-\mathrm{F}\right)-\mathrm{D}_{298}\left(\mathrm{C}_{1}-\mathrm{C}_{1}\right)=29.7$ kcal $\mathrm{mol}^{-1}=1.28 \mathrm{eV}$ stronger than the $\mathrm{C}_{1}-\mathrm{C}_{1}$ bonds.

\section{Conclusion}

Very precise values of the threshold energies for the molecular and fragment ions can be obtained by photoionization, but there is no reason to assume a priori that those values correspond to the adiabatic transition.

It is shown in this paper that in some cases the total excess energy with which the ions are obtained at threshold can be different from zero by amounts that cannot be neglected. Nevertheless, in the present state of the art, when this excess energy can be determined, photoionization can give dissociation energy values as good or better than direct thermochemical methods.

I am indebted to H. M. Rosenstock, V. H. Dibeler, G. T. Armstrong, and W. H. Evans for very helpful suggestions and discussions and to the International

TABLE 4 .

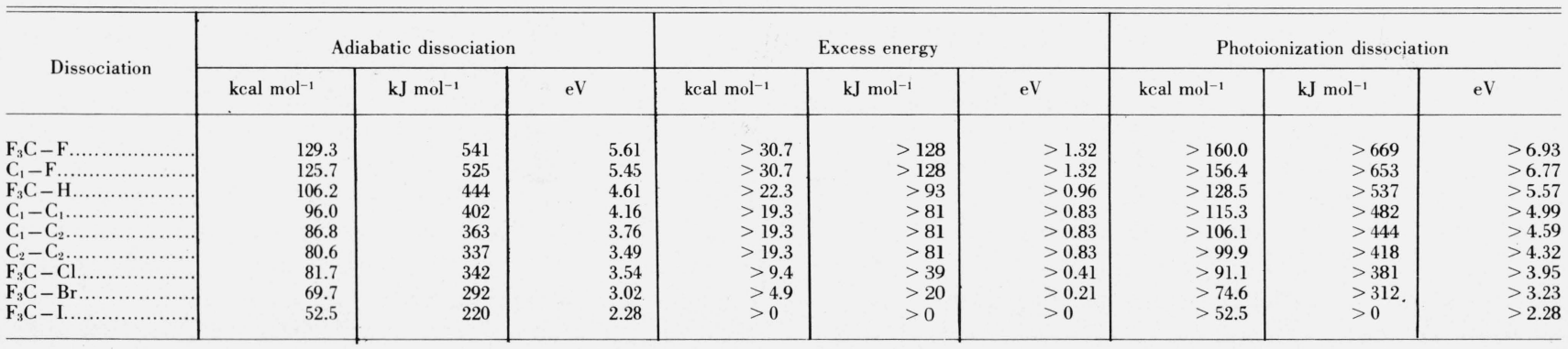


Atomic Energy Agency (Vienna, Austria), The National Academy of Sciences (Washington, D.C.), and the Comisión Nacional de Energía Atómica (Buenos Aires, Argentina) for their financial support.

It's a pleasure for me to acknowledge the valuable assistance of Miss Susan Kay Liston and Miss Rosemary Suckow, who obtained some of the photoionization yield curves, and of J. A. Walker for maintenance of the instrument.

\section{References}

[1] Mohler, F. L., Dibeler, V. H., and Reese, R. M., J. Res. NBS 49, 343 (1952) RP2370.

[2] Dibeler, V. H., Reese, R. M., and Mohler, F. L., J. Res. NBS 57, 113 (1956) RP2700.

[3] Marriott, J., and Craggs, J. D., J. Electronics 1, 405 (1956).

[4] Bibby, M. M., and Carter, G., Trans. Faraday Soc. 59, 2455 (1963).

[5] Dorman, F. H., J. Chem. Phys. 41, 2857 (1954).

[6] Pottie, R. F., J. Chem. Phys. 42, 2607 (1965).

[7] Bibby, M. M., Toubelis, B. J., and Carter, F., Electronic Letters 1, 51 (1965).

[8] Lifschitz, C., and Long, F. A., J. Phys. Chem. 69, 3746 (1965).

[9] Fisher, I. P., Homer, J. B., and Lossing, F. P., J. Am. Chem. Soc, 87, 957 (1965).

[10] Kiser, R. W., and Hobrock, D. L., J. Am. Chem. Soc. 87, 922 (1965).

[11] Forman, F. H., J. Chem. Phys. 44, 35 (1966).

[12] Cook, G. R., and Ching, B. K., J. Chem. Phys. 43, 1794 (1963).

[13] NBS Circular 500.

[14] NBS Technical Note 270-3, Wagman, D. D., Evans, W. H., Halow, I., Parker, V. B., Bailey, S. M., and Schumm, R. H. (January 1968).

[15] JANAF TABLES - The Dow Chemical Co.

[16] Sinke, G. C., J. Chem. Eng. Data 10,295 (1965).

[17] Tschuikow-Roux, E., J. Phys. Chem. 69, 1075-1077 (1965).

[18] Tschuikow-Roux, E., J. Chem. Phys. 43, 2251 (1965).
[19] Coomber, J. W., and Whittle, E., Trans. Faraday Soc. 62, 2183 (1966).

[20] Coomber, J. W., and Whittle, E., Trans. Faraday Soc. 63, 608 (1967).

[21] Coomber, J. W., and Whittle, E., Trans. Faraday Soc. 63, 1394 (1967).

[22] Sinke, G. A., J. Phys. Chem. 70, 1326 (1966).

[23] Lord, A., Goy, C. A., and Pritchard, H. D., mentioned by Lacher and Skinner [29] to be published.

[24] Goy, C. A., Lord, A., and Pritchard, H. D., J. Phys. Chem. 71, 1086-9 (1967).

[25] Ampheett, J. C., Coomber, J. W., and Whittle, E., J. Phys. Chem. 70, 593-4 (1966).

[26] Fessenden, R. W., and Schuler, R. H., J. Chem. Phys. 43, 2704 (1965).

[27] Benson, S. W., Chem. Educ. 42, 502 (1965).

[28] Kerr, J. A., Chem. Reviews 66, 465 (1966).

[29] Lacher, J. R., and Skinner, H. A., (private communication).

[30] Johnson, G. K., Feder, H. M., and Hubbard, W. N., J. Phys. Chem. 70, 1 (1966).

[31] Domalski, E. S., and Armstrong, G. T., J. Res. NBS 71A (Phys. and Chem.), No. 2, 105 (1967).

[32] Lifshitz, C., and Chupka, W. A., J. Chem. Phys. 47, 3439 (1967).

[33] Dibeler, V. H., and Reese, R. M., J. Res. NBS A68 (Phys. and Chem.), No. 4, 409 (1964).

[34] Wheaton, J. E. G., J. Opt. Soc. Am. 54, 1287 (1964).

[35] Chupka, W. A., and Berkowitz, J., J. Chem. Phys. 47, 2921 (1967), Steiner, B., Giese, C. F., and Inghram, M. G., J. Chem. Phys. 34, 189 (1961), Dibeler, V. H., Krauss, M., Reese, R. M., and Harlee, F. N., J. Chem. Phys. 42, 3791 (1965).

[36] Interatomic Distances, Special Publ. No. 18 and Suppl., The Chemical Society (London, 1965).

[37a] Walsh, A. D., J. Chem. Soc., p. 2260-2330 (1953).

[37b] Jahn, H. A., and Teller, E., Proc. Roy. Soc. (London) A161, 220 (1937).

[38] Pauling, L., The Nature of the Chemical Bond, p. 237 (Cornell University Press, Ithaca, N.Y., 1945).

[39] Cotton, F. A., and Letto, J. R., J. Chem. Phys. 30, 993 (1959).

[40] Rosenstock, H. M., Doctoral Thesis, University of Utah (1954).

[41] Palko, A. A., and Drury, S., J. Chem. Phys. 47, 2561 (1967).

(Paper 72A5-515) 